\title{
Protocol for Transferring Bare-rooted Native Plant Seedlings to Restoration Sites - Preventing the Spread of Invasive Species Contaminants
}

\author{
David Beaune ${ }^{1,2}$, Jean-François Butaud ${ }^{1,3}$, Souad Boudjelas ${ }^{4}$ \\ ${ }^{1}$ Société d'Ornithologie de Polynésie, Manu BP 7023 - 98719 Taravao - Tahiti - Polynésie française. \\ ${ }^{2}$ Biogéosciences, UMR 6282 CNRS, Université Bourgogne Franche-Comté - 6 Boulevard Gabriel, 21000 Dijon, \\ France. \\ ${ }^{3}$ Consultant en foresterie et botanique polynésienne BP 52832 - 98716 Pirae, Tahiti - Polynésie Française; \\ ${ }^{4}$ Pacific Invasives Initiative (PII) C/- School of Biological Sciences. University of Auckland. Private bag 92019, \\ Auckland, New Zealand.
}

*Corresponding Author: David Beaune, Société d'Ornithologie de Polynésie, Manu BP 7023 - 98719

Taravao - Tahiti - Polynésie française, david.beaune@gmail.com, sop@manu.pf

\begin{abstract}
Seedling transfer is commonly used for restoration ecology, however, still many projects do not take into consideration the risk of invasive species contaminants, especially invisible contaminants such as eggs, seeds, spores, mycelium, and small-sized organisms. Here we reviewed literature in order to provide a low cost and simple protocol to avoid the spread of invasive species in forests and other restored sites in four summarized points used in a restoration project in a Tahitian forest (French Polynesia). 1- minimize distance between nursery and transplantation site; 2- use sterile or neutral substrate (from the transplantation site), isolate from the surrounding soil; 3-treat against fungi and invertebrates; 4-avoid substrate transport prior to transfer to transplantation site.
\end{abstract}

\section{INTRODUCTION}

Invasive alien species are found in all taxa groups: fauna, flora, fungi, bacteria, etc. Globally, they are one of the top five causes of biodiversity loss. However, their impacts are particularly severe on islands. Often, attention is focused on invasive macro organisms, yet, microorganisms have important ecological functions, and the transfer of soil from one environment to another carries risks of introduction of non-native soil species (associated with the rhizosphere or substrate). These organisms can have a significant impact on the functioning of soils and the biology of native plants. For example, in California, several species in the Phytophthora group have been introduced through the transport of nursery stock containing soil. This group of fungi whose name means 'plant destroyer' has had and is still having devastating impacts on plant communities around the world, profoundly modifying affected ecosystems (Rizzo et al., 2002; Davidson et al., 2005). In Spain, the introduction of Phytophthora cinnamomi has contributed to the decline of populations of Quercus suber and $Q$. ilex in the Iberian Peninsula (Brasier et al., 1993). Managers should be aware of the risks posed by invasive microorganisms. In addition to invasive microorganisms, soil can also harbour invasive species such as ants, slugs, snails, lizards, etc. Soil was, and still is frequently moved from place to place for construction, earthworks and horticulture purposes. Thus, invasive ants such as the little fire ant (Wasmannia auropunctata (Roger, 1863)) or the yellow crazy ant (Anoplolepis gracilipes (Smith, 1857)) probably arrived in Polynesia via such pathways and can spread from one island to another due to a lack of adequate biosecurity measures. Soil transfer can also take place for ecological restoration purposes, such as the translocation or reintroduction of rare plants grown ex-situ (e.g. in nurseries) to natural sites. Controlling the risks of transporting invasive species with soil is therefore a major challenge. A rigorous $e x$-situ native plant transfer protocol should prevent the introduction of invasive microorganisms. There follows some recommendations and an example of a project being undertaken 
Protocol for Transferring Barerooted Native Plant Seedlings to Restoration Sites - Preventing the Spread of Invasive Species Contaminants

in Tahiti, French Polynesia to restore key habitats of the critically endangered Tahiti Monarch (Pomarea nigra (Sparrman, 1786)) (IUCN, 2018):

\section{The distance between the plant propagation and the restoration sites should be minimized}

This should theoretically limit the exogenous characteristics of the biological community of the soil. Ideally, the nursery where the plants are being propagated should be situated on site to minimize the risk of introduction of invasive microorganisms and other pests. Unfortunately, the principle of $e x$-situ plant propagation is to control the ecological factors to optimise production, thus very few programs are able to do this, therefore, it is necessary to limit the distance.

\section{The growing medium should be neutral and sterile}

For managers, this option may be too expensive. An alternative is to use the substrate from the restoration site. This substrate should be isolated from any soil in the nursery. For example, keep potted plants on a bench to avoid contact with the ground and limit contamination from any surrounding soil (Fig. 1).

\section{Seedlings should be treated prior to transfer}

Treat seedlings with systemic insecticides and fungicides just before transferring them to the planting site to remove any invertebrates and fungi contamination. Follow label and safety Data Sheets when using insecticides and fungicides, especially noting the time lapse prior to transfer, for optimal efficiency.

\section{Seedlings should be transferred bare-rooted}

Remove as much soil as possible from the roots of seedlings a few hours prior to transplanting. Care should be taken not to damage mats and rootlets. There may be a need for a compromise to ensure successful recovery of the transplanted plants, especially for delicate rare species and when the restoration site requires several hours of work. Using a pressure hose to wash the roots can be effective in removing most of the soil. Special attention should be paid to soil types that are difficult to remove, such as clay.

\section{An example of a nursery for a restoration project in Tahiti}

On Tahiti, key habitats for the Tahiti monarch are highly threatened by several introduced tree species such as miconia (Miconia calvescens) and the African tulip tree (Spathodea campanulata) which can form monospecific stands, overtaking native habitats and altering ecosystems (Meyer, 1996; Spotswood et al., 2012). A project aiming to restore the monarch's habitats through revegetation with native tree species and control of invasive tree species is currently underway. Twelve native tree species originally present in the habitats have been selected for propagation: Neonauclea forsteri, Rhus taitensis, Ficus prolixa, Serianthes myriadenia, Terminalia glabrata, Tarenna sambucina, Pisonia tahitensis, Pandanus tectorius, Pandanus papenooensis, Pipturus argenteus, Premna serratifolia, and Morinda citrifolia.

Plant propagation was carried out by three nurseries of which one is located in Papara and the other two in Taravao which are $10 \mathrm{~km}$ and $30 \mathrm{~km}$ respectively from Maruapo, Papehue and Hopa valleys where the restoration sites are located. The growing medium is made up of $50 \%$ river sand and $50 \%$ soil, collected from Papehue valley or a commercial sterile substrate.

To avoid contact with the ground and prevent contamination, propagation plastic pouches/planter bags are kept on a $50 \mathrm{~cm}$ high platform made up of breeze blocks at the nursery in Papara and on $120 \mathrm{~cm}$ high barrels at the Taravao nurseries. Seedlings are treated with insecticide to remove insects before transport. Prior to transfer to the planting site, all the soil from the root system was manually removed, by dipping the roots in water and/or washing them with a pressure hose.

In 2016-2017, more than 772 seedlings were transferred to the restoration sites and planted with the help of volunteers (school children, supporters and members of the Ornithological Society of Polynesia). Thirty seedlings (10 N. forsteri, $5 \mathrm{~F}$. prolixa, $5 \mathrm{~S}$. myriadenia, $5 \mathrm{~T}$. glabrata, $5 \mathrm{M}$. citrifolia) were monitored in October 2017 after a month of transplantation and $100 \%$ were alive despite the bare root treatment. To date, there haven't been any new invasive species detected at the site. 


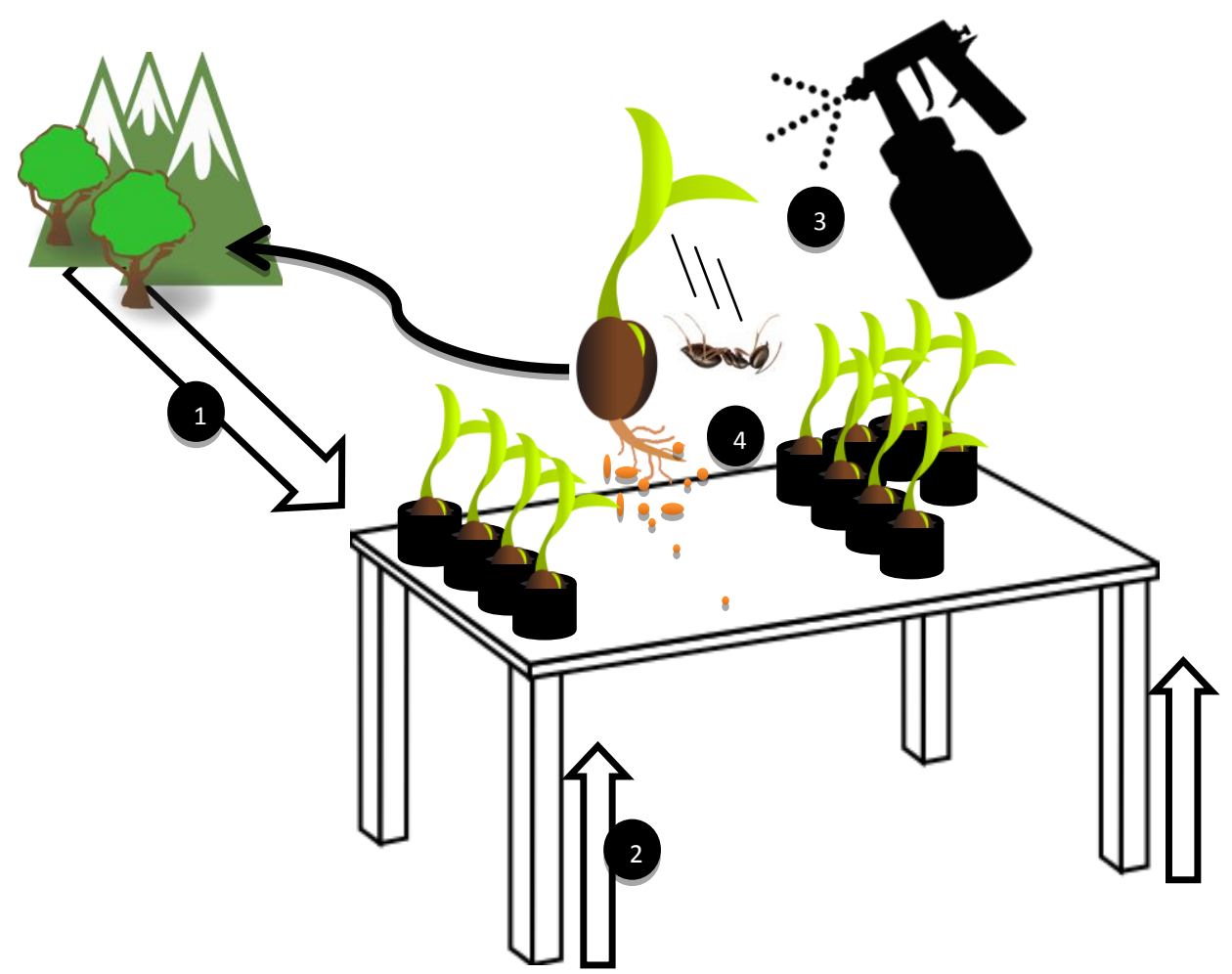

Figure 1. Protocol for transferring bare-rooted native plant seedlings to restoration sites. 1 - minimize distance between nursery and transplantation site; 2- use sterile or neutral substrate (from the transplantation site), isolate from the surrounding soil; 3-treat against fungi and invertebrates; 4-avoid substrate transport prior to transfer to transplantation site.

\section{ACKNOWLEDGMENT}

This conservation project is funded by the European Union (Program BEST 2.0 \#1058); the Direction de l'Environnement (DIREN), French Polynesia; BirdLife International, Punaauia districts, donors and other sponsors including EDT, Yune Tune, Vini and OPT. We are grateful to all the volunteers and SOP members for their help on this project.

\section{REFERENCES}

BRASIER, C.; ROBREDO, F.; FERRAZ, J. Evidence for Phytophthora cinnamomi involvement in Iberian oak decline. Plant Pathology, v. 42, n. 1, p. 140-145, 1993. ISSN 1365-3059.

DAVIDSON, J. M. et al. Transmission of Phytophthora ramorum in mixed-evergreen forest in California. Phytopathology, v. 95, n. 5, p. 587-596, 2005. ISSN 0031-949X.

MEYER, J.-Y. Status of Miconia calvescens (Melastomataceae), a dominant invasive tree in the Society Islands (French Polynesia). Pacific Science, v. 50, n. 1, p. 66-76, 1996. ISSN 0030-8870.

RIZZO, D. et al. Phytophthora ramorum as the cause of extensive mortality of Quercus spp. and Lithocarpusdensiflorus in California. Plant disease, v. 86, n. 3, p. 205-214, 2002. ISSN 0191-2917.

SPOTSWOOD, E. N.; MEYER, J. Y.; BARTOLOME, J. W. An invasive tree alters the structure of seed dispersal networks between birds and plants in French Polynesia. Journal of Biogeography, v. 39, n. 11, p. 2007-2020, 2012. ISSN 1365-2699.

Citation: D. Beaune et al., " Protocol for Transferring Bare-rooted Native Plant Seedlings to Restoration Sites - Preventing the Spread of Invasive Species Contaminants ", International Journal of Research in Environmental Science, vol. 4, no. 1, p. 73-75, 2018. http://dx.doi.org/10.20431/2454-9444.0401009

Copyright: (C) 2018 Authors. This is an open-access article distributed under the terms of the Creative Commons Attribution License, which permits unrestricted use, distribution, and reproduction in any medium, provided the original author and source are credited. 